УДК 82I.I6I.I+82I.II2.5

ББК $83.3(2 \mathrm{Poc}=$ Рус $)+$

86.4(4Нид)
ГОЛЛАНДСКАЯ СВЯЗЬ: ВКЛАД

ЙОХАННЫ ВАН ДЕР МЕЙЛЕН В РУССКИЙ СИМВОЛИЗМ

\author{
(C) 2017 г. М. Юнггрен \\ Гетеборгский универстет \\ Стокгольм, Швеция \\ Дата поступления статьи: 25 марта 2017 г. \\ Дата публикации:25 сентября 2017 г.
}

DOI: IO.22455/2500-4247-20I7-2-3-190-203

Аннотация: Произведения символиста Эллиса (Льва Кобылинского), относящиеся к московскому периоду, акцентируют разрыв, разделение и дихотомию между материальной действительностью и неземным ви́дением. Произведения, написанные в годы эмиграции в швейцарском Локарно-Монти, пытались разрешить эти противоречия путем наведения мостов между католицизмом и православием, культурой и религией, земным и потусторонним и, наконец, между Востоком и Западом. Поэт и критик, Эллис стал переводчиком и культурологом, «доктором Лео Кобылинским-Эллисом». Голландская медиум Йоханна ван дер Мейлен, которую он встретил в теософской (в скором времени антропософской) общине Рудольфа Штайнера, сыграла ключевую роль в этой фундаментальной для Эллиса метаморфозе. С ней он прожил тридцать пять лет и их союз оказался невероятно благотворным для обоих. Ван дер Мейлен разработала собственную мистическую доктрину под названием «Космософия», основанную на гностическом мировидении и написанную под сильным влиянием русской религиозной философии. Доктор Кобылинский-Эллис опубликовал синопсис и собственную интерпретацию ее тетралогии, где он определяет сущность Космософии как синтез «иоаннического» элемента медитативной мудрости восточной церкви и «петровского» компонента в энергической вере католицизма.

ключевые слова: Эллис, Ван дер Мейлен, Творческий симбиоз, Мистическая доктрина. Космософия. Гностицизм. Католицизм. Культурный синтез.

Информация об авторе: Магнус Льюнгрен, почетный профессор русской литературы. Университет Готенбурга. Gröndalsvägen I77, II7 69 Stockholm, Sweden.

E-mail: magnusljunggren@telia.com 


\section{THE DUTCH CONNECTION: JOHANNA VAN DER MEULEN'S CONTRIBUTION TO RUSSIAN SYMBOLISM}

This is an open access article distributed under the Creative Commons Attribution 4.0 International (CC BY 4.0)
(C) 20I7. M. Ljunggren

University of Gothenburg, Stockholm, Sweden

Received: March 25, 2017

Date of publication: September 25, 2017

Abstract: The Symbolist Ėllis' (Lev Kobylinskij) writings during his Moscow period emphasize the split, the division and dichotomy between material reality and celestial vision. His works written in exile in Locarno-Monti in Switzerland are devoted to resolving these antitheses by building bridges on all levels: between Catholicism and Orthodoxy, between culture and religion, between worldly and otherworldly, ultimately between East and West. From being a poet and critic he became a translator and culturologist: "Dr. Leo Kobilinski-Ellis.” The Dutch medium Johanna van der Meulen - whom he had met in I9II in Rudolf Steiner's Theosophical, soon Anthroposophical colony - played a crucial role in this fundamental metamorphosis. With her he lived in a thirty-five-yearlong creative symbiosis that proved extremely beneficial to the two of them. Van der Meulen developed a mystical doctrine of her own, "Cosmosophy”, based on a Gnostic world view, strongly influenced by Russian religious philosophy. As she had finished her work in four parts Dr. Kobilinski-Ellis published his summary and interpretation of her teachings, in which he defines the core of Cosmosophy as a synthesis of the "Johannian" element in the meditative wisdom of the Eastern Church and the "Petrine" component in the energetic faith of Catholicism.

Keywords: Ellis, Van der Meulen, symbiosis, mystical doctrine, cosmosophy, gnosticism, catholocism, cultural.

Information about the author: Magnus Ljunggren, Professor Emeritus of Russian literature at the University of Gothenburg. Gröndalsvägen I77, II7 69 Stockholm, Sweden.

E-mail: magnusljunggren@telia.com 
Lev Kobylinskij's biography can be divided into two halves. First he is Ėllis the Russian Symbolist, visionary and rebel. Then, in exile in southern Switzerland, he becomes a synthesizer who strives above all to help heal the almost thousand-year-old schism between the Eastern Orthodox and Western Catholic Churches. His writings in Moscow emphasize the split, the division and dichotomy between material reality and celestial vision. The works written in Locarno-Monti are devoted to resolving these antitheses by building bridges on all levels: between Catholicism and Orthodoxy, culture and religion, worldly and otherworldly. It also led him to change genres. From being a poet and critic he becomes a translator and culturologist: "Dr. Leo Kobilinski-Ellis" [7].

Lev Kobylinskij's friend Johanna van der Meulen played a crucial role in his metamorphosis. His "change of skin" would have been inconceivable without her active involvement. As the woman who helped transmit one of the central tendencies in Russian Symbolism, she deserves to be presented in more detail. Who was she? How could she become so important? [I7, p. I79-I8I; Io; 8, p. 806-8I4].

Johanna van der Meulen was born in 1874 in Bussum, twenty kilometers southeast of Amsterdam. Her family was well-off, her father being the president of a mortgage bank, and she received a Protestant upbringing. She showed a talent for languages at an early age, and in addition to her native Dutch she eventually became fluent in German, Italian, English, Spanish, and to some degree Russian. Practical by nature, she at the same time had spiritual experiences that first led her to Spiritism and then to Theosophy. During a visit to England she became a pupil of Annie Besant, and she was deeply interested in astrology. Ac- 
companied by her husband John (Johannes) Polman-Mooij, around I909 she turned to Rudolf Steiner, who headed the German section of the Theosophical Society. The couple followed Steiner's lectures across Europe, and eventually he delegated to her the responsible task of holding "esoteric lessons" in accordance with his instructions for a circle of initiates [2, p. 370]. When in the summer of I9I2 Steiner broke with Theosophy, she unhesitatingly made common cause with him.

At that point she had already met the Russian rebel. Steiner had found it difficult to cope with his intense personality and assigned van der Meulen to "tame" him. She did so with amazing results. On 6 May I9I2, shortly after she and Ėllis had really gotten to know each other, Ėllis wrote delightedly to Ėmilij Metner: "ja vstretil sredi intimnych učenic Doktora odnu - soveršenno prekrasnuju Damu, kotoraja pomnit menja v prežnej inkarnacii, imenno v srednevekovoj, o kotoroj Doktor govoril mne, kak o real'nom pereživanii mnoju moich simvoličeskich grez teperešnich." He describes their meeting as a "neverojatnoe sobytie v moej žizni." "This was hardly an overstatement, for their respective needs complemented each other remarkably well. Ėllis's complicated relationship to his mother had ended in a falling out. As is amply clear from his poetry, he continued to deeply identify with the abandoned child [7, p. 70-7I]. For her part, Johanna van der Meulen was by nature strongly altruistic and was known to take both animals and people under her maternal wing. He looked to the West for guidance, while she was attracted to Eastern mysticism and reportedly had already read Vladimir Solov'ev in translation.

Subsequently it becomes more and more difficult to distinguish between Ėllis and van der Meulen, for the creative pact they concluded erased their boundaries. To his Dutch partner Ėllis brought in particular his Russian experience. As for her, she was now involved with developing a mystical doctrine of her own that increasingly deviated from and competed with the Anthroposophical movement Steiner had just founded around the turn of the year I9I2-I9I3. By the spring of I9I3 she and Ėllis were already heading toward a new break, this time with Steiner himself, in favor of van der Meulen's "Astrosophy" or "Cosmosophy," which aspired to establish an esoteric Christianity that was closer to religion than his so called spiritual science. Steiner, she thought,

I Letter of 6 May I9I2 to Ėmilij Metner (РГБ. Ф. г67. Карт. 7. Ед. хр. 59, 1. I), quoted in [I5, p. 310 (note)]. 
had betrayed his fundamental Rosicrucianism. A trip that van der Meulen, Ėllis and Polman-Mooij made to Italy consolidated their turn toward Catholicism².

Van der Meulen was working on an Astro/Cosmosophical tract and regarded herself as a medium, a tool of a higher wisdom that guided her pen. Ėllis, who joked about Anthroposophical feminism and thought that both Belyj and Steiner were under the thumb of their domineering wives 3 , greatly admired her writing, to which he himself contributed. Eventually he undertook a translation of the work, intending to publish it with Orfej, a branch of Medtner's Musaget, which at the time was about to collapse due to Andrej Belyj's move to Anthroposophy.

It is worth noting that Belyj, who was deeply troubled by Ėllis's defection, later noted that he very much missed his conversations with van der Meulen as well. It was she and Ėllis who had introduced Belyj and Asja Turgeneva to the new spiritual worlds. Belyj put special emphasis on the Dutch woman's intellect, acumen and culture. In short, she was an "exceptional nature" who was capable of defining certain of the new states of consciousness that Belyj had achieved in the meditation exercises prescribed by Steiner [I, p. 780, 782, 787]. From their intense meetings in Stuttgart in the fall of I9I2 he recalled her as "vysokaja, tonkaja, kak osa, s interesnym licom, s oslepitel'nymi sero-sinimi, kristal'nymi glazami i s černymi volosami, - v černejuščem tunike, v černoj stole is krestom na grudi, obramlennym puncovymi rozami” [I, p. 793].

Who was responsible for the break with Rudolf Steiner? Steiner's wife Marie von Sivers blamed everything on van der Meulen's "pride" [4, p. 356]. For his part, Belyj maintains that Ėllis was upset because Steiner did not give her the recognition she deserved and therefore "stirred her up" against him [I, p. 794]. It is a fact that in his maximalist pamphlet "Vigilemus" published with Musaget in the spring of I9I4, Ėllis vehemently rebelled against Steiner, whereas van der Meulen continued to show him respect and even visited the new Anthroposophical commune in Dornach [Io, p. 66].

\footnotetext{
2 A poem from this period entitled "Svjataja Kniga" (published in Ėllis's last collection Argo in I9I4), depicts St. Teresa of Avila receiving her visionary vocation as a child. Van der Meulen had a similar experience, which renders the dedication of the poem to her especially suggestive (see [5, p. I22-I23]).

3 Ėmilij Metner's letter of 4 April (dated 5 April) 1915 to his wife Anna (РГБ. Ф. І67. Оп. І. Карт. 25. Ед. хр. 6).
} 
At the same time as "Vigilemus!", van der Meulen's debut work "Christliche Theologie und Cosmosophie nach dem Zeichen des Heiligen Graal” appeared in Leipzig. She signed it "Intermediarius," which remarkably enough was a masculine pseudonym intended to emphasize her role as a go-between. She was not out to advertise herself.

The work is based on a Gnostic worldview. Our universe is divided into cosmos and chaos. Due to Lucifer's interference, we humans broke away from our holy origins. Christ's act of redemption on the cross points the way to our future resurrection. After Golgotha the earthly strives to reunite with the divine. We have entered an apocalyptic time. Modern humanity is deepening its consciousness and awakening to the world's being and unity with the astral cosmos.

At the outbreak of WWI, Metner (deeply hurt by Belyj's break with his publishing house), Ėllis and van der Meulen were deported from Germany to Switzerland. They all met there, and van der Meulen made a strong impression on Metner. After visiting her and Ellis in January I9I5 outside Basel (near the Anthroposophical commune in Dornach), he wrote to his wife Anna that they were in a solid spiritual (but not physical) relationship and were economically secure, which of course made their life considerably easier. He emphasized that he had never been able to guess van der Meulen's nationality. Her intellect and wide reading led him to suspect she might be Jewish, yet there was also something American in her demeanor. Her smile radiated goodness and motherliness: she laughed at Ėllis's mischief as though he were a little child. She dressed tastefully and stylishly and in every way had an aura of "distinction"4.

In many respects van der Meulen's ideas were in line with those of the Germanophile Metner. She declared that German culture (to which she regarded herself as belonging) and Russian culture were "karmically bound" to each other. Under the palpable influence of her partner, she warned of the femininity inherent in men as well, who because of their proximity to chaos needed to be subdued5.

Metner, who due to his difficult predicament had begun intensive therapy with Carl Gustav Jung, found obvious similarities between Cosmosophy and

4 Metner's letter of Ir January (dated 22 January) I9I5 to Anna (РГБ. Ф. І67. Оп. г. Карт. 24. Ед. хр. 48).

5 Metner's letter of 2I January (dated 23 January) I9I5 to Anna (РГБ. Ф. І67. ОП. І. Карт. 24. Ед. хр. 49). See also [12, p. І02]. 
Jungian psychology. Van der Meulen had concluded that many dreams contain an objective and a subjective meaning: objectively they confront the dreamer with future tasks, while subjectively they point to events in his or her past, possibly even in earlier incarnations. Not long before this Jung had expressed almost the same idea during a session with Metner: "The unconscious presents to us in symbols details from the past that are usable in the future, the materials with which the future is to be built" 6 .

A few months later Metner wrote enthusiastically to Anna that van der Meulen was "simple in her sublimity and sublime in her simplicity." In her proximity he felt transported to "an atmosphere of absolute purity." He strolled with the couple around the Wallensee, near which they were staying during the summer of I9I5. Because she "understood everything," Metner found it easier to discuss the occult and his complex dealings with the Anthroposophists with her than he did with Ėllis. ${ }^{7}$ Via Ėllis she was already familiar with the anti-Steiner polemic he presented in Razmyšlenija o Gete in connection with Belyj's apostasy.

John Polman-Mooij was against a divorce, which led to two trials in I9I6-I9I7. Two wings among the Anthroposophists were represented in court. Belyj suddenly found himself in the van der Meulen camp and, faced with the prospect that the Polman-Mooij side (which also included Steiner's wife Marie von Sivers) would cast suspicion on Ėllis, was prepared to testify in favor of his erstwhile friend ${ }^{8}$. He did not need to do so, as in the end van der Meulen won both cases [3].

In the final issue of the Musaget journal Trudy i dni (I9I6) van der Meulen published Ėllis's translation of her "Astrosophical" commentary on Dante [I6]. His appreciation of his friend and colleague reached new heights at this time, as he put her work on an equal footing with The Divine Comedy itself. Soon he was hoping that the Russian translation of her tract published with Orfej would help give Russia direction in its revolutionary turmoil. Belyj allotted

\footnotetext{
6 The above-mentioned letter of II January (dated 2I January) I9I5 to Anna.

7 Metner's letter of August 1915 to Anna (Ponsov family archive, now at РГБ).

8 Letter in the spring of I9I6 from Belyj to Natalija Turgeneva-Pozzo. According to Metner's letter of 8 June I916 to her, the partisans of Polman-Mooij had on the contrary counted on Belyj's support. (Both letters are in the Turgeneva-Pozzo file in the Goetheanum archive in Dornach.)
} 
a similar role to Anthroposophy, and Metner attempted to interpret the Russian political drama on the basis of Jung. Paradoxically enough, it was a woman whom the gynophobic Ėllis wanted to view as the person who could offer Russia healing in this fateful historical moment 9

In I9I8 the second part of van der Meulen's mystical doctrine appeared in Basel. Entitled Homo Coelestis. Das Urbild der Menschheit, it developed her account of how humanity lost its natural place in a celestial whole and became isolated in time and space.

In I9I9 van der Meulen and Ėllis turned southward, settling in Italian-speaking Locarno-Monti, where they bought a house with a magnificent view of Lake Maggiore. They were doubtless trying to come nearer to medieval Catholic culture. For that purpose Monti della Trinità - Mount Trinity - overlooking Locarno was an ideal starting point, located as it is near the famous Madonna del Sasso Monastery built on the site of a Franciscan monk's vision of the Virgin Mary. Franciscan piety seems to have been if anything even more important to van der Meulen than it was to Ėllis.

In I920 Metner arrived for an extended visit. He had been in Monti as early as I9I5 and perhaps to some degree inspired the couple to move there. Before long, however, the guest came into conflict with his host. It turned out that Metner's faithful partisan could not accept his master and - to some extent benefactor - Jung. Ėllis dismissed Jung’s analytical psychology as "black magic," and that sealed the break [9, p. 4IO].

Van der Meulen stayed in the background, working on her third volume, Der Cosmos und der cosmische Mensch. Liber Mundi, which came out in Basel in I922. Its message was the same: the global mission is to restore the lost equilibrium, revitalize the cosmic individual, put an end to earthly dualism. As for Dr. Kobilinski, around this time, he began in earnest writing a series of works in German, devoting special attention to translating and presenting texts by Vladimir Solov'ev [I7, p. I9I-203; I4]. Van der Meulen obviously helped him with the language, but certainly not only with that.

The couple's house had been christened in the Franciscan manner "Casa Fioretti," and next to it van der Meulen had a little outdoor temple built that

9 Ėllis thought that van der Meulen would bring to life the slumbering Orfej publishing house (by assuming the future leadership of the Musaget project). See [3]. 
featured a fresco depicting St. Francis surrounded by animals. ${ }^{\text {Io }}$ They were seen attending Mass at Madonna del Sasso every Sunday. They lived a quiet, affluent life, adhering to regular daily routines. Van der Meulen managed their finances and household matters. It was she who quite naturally took charge of Dr. Kobilinski's income. He lived on the upper floor of the house, while she had command of the first floor, including the study and kitchen.

In 1928 van der Meulen finished her tetralogy with Das Grosse Zeichen. Arcana sapientiae, also published in Basel. It highlights Golgotha as the critical juncture in history, the point at which the redemption of the world begins under the sign of the rose and the cross. It also marks the revelation of the "true esotericism" that for two millennia had been trying to assert itself in a struggle with repressive matter.

In 1929 Dr. Kobilinski published his summary and interpretation of van der Meulen's teachings: Christliche Weisheit. Sapientia divina. Cosmologia perennis nach der Lehre des Intermediarius, in which he defines the core of Cosmosophy as a synthesis of the "Johannian" element in the meditative wisdom of the Eastern Church and the "Petrine" component in the energetic faith of Catholicism, a notion that he views as naturally related to Vladimir Solov'ev's universalism and Sophiology [II, p. 29, 4I (note), 97 (note), I33 (note)]. The book is dedicated "with reverence" to "Intermediarius."

Dr. Kobilinski was a diligent letter writer. Characteristically enough, there was some uncertainty among his friends and contacts as to the identity of "Intermediarius." For example, Vice-Mayor of Vienna (until 1936) Ernst Karl Winter, who was very interested in ecumenicalism, believed to the last that it was a case of Kobilinski broadening his horizons, and Dr. Kobilinski himself did little to disabuse him ${ }^{\mathrm{II}}$.

A reprint of van der Meulen's tetralogy appeared in Bad Wörishofen, Germany in 1933. Her life's work was now behind her, but she continued to support her friend and gave special attention to the linguistic side of his articles and books, which in itself was a significant contribution. She converted to Catholicism, while as Kobilinski himself puts it, his Solovyovian, ecumenical

Io Conversation in November 199I with Elisabeth Rezzonico-Valentin, widow of composer Lucas Valentin, Dr. Kobilinski's close friend and collaborator in Monti.

II Typewritten copy in my possession (a gift from Reimund Egger, I988) with statements about "Intermediarius" by Ernst Karl Winter, Franz Wetzel, Fra Tedesco and Alois Mager. 
aspirations led him to the Uniate Church [13, p. 367 $]^{\mathrm{I2}}$. Behind his back van der Meulen hinted to another neighbor, Lore Müller, that no one before her had really understood her partner. Müller recalled later that the couple surrounded themselves with a large Newfoundland dog, another smaller dog, two pedigree cats and two turtles. St. Francis was their life's ideal'3.

During the early I940s Kobilinski suffered from severe depression caused in part by the extreme difficulty he encountered publishing anything in the increasingly grim atmosphere of those years. He died in 1947 in Bellinzona.

At about this time the radical theologian August Zechmeister in Vienna discovered "Intermediarius"” writings. He and his circle of adherents began studying and learning from them. In the postwar climate that reigned in Allied-occupied Austria he joined a leftist movement that promoted intercultural understanding and bridge building. Suddenly "Intermediarius" synthetic idea seemed relevant [8]. Eventually the Vienna group managed to get in touch with van der Meulen. In I95I she answered their questions in a letter, strongly downplaying her personal contribution to the tetralogy: "Der Pseudonim 'Intermediarius' habe ich gewählt, weil beim Schreiben esoterischen Büchern der Verfasser nur als Vermittler betrachtet werden muss, sonst kommt das persönliche Element leicht zu viel auf den Vordergrund. Hauptsache ist, dass jene esoterisch-christliche Weisheitslehre überliefert wird, ungetrübt von persönlichen Denken, Empfinden und Wollen." She did, however, include the photograph of herself that her Vienna followers had requested ${ }^{\mathrm{in}}$.

Van der Meulen obviously had difficulty coping with loneliness. In the early I950s, a Sicilian gardener and father of six by the name of Rosario was going around Monti looking for work. Van der Meulen hired him, which to some extent again gave her someone to support. She also traveled with him a couple of times to his native Sicily. On December 30 I953 in Palermo she suddenly died of a heart attack. Up until then she had reportedly been thoroughly healthy. Some said that the Sicilian had hoped for an inheritance and seemed disappointed when in accordance with the will, all of her assets went

\footnotetext{
I2 I confirmed this information in several conversations with Elisabeth Rezzonico-Valentin.

I3 Conversations with the Monti neighbour Lore Müller, who in the I930s was in regular contact with van der Meulen and Kobilinski.

I4 Van der Meulen, Johanna. Letter of I7 July 195I to Reimund Egger (copy in my archive). Her orthography has been preserved.
} 
to van der Meulen's Dutch relatives ${ }^{15}$. Soon rumors were circulating among her neighbors in Monti that something about her death was not quite right ${ }^{16}$. Thus the restless Symbolist Ėllis and the Dutch medium van der Meulen entered into a thirty-five-year-long creative symbiosis that proved extremely beneficial to the two of them and for Lev Kobylinskij in particular brought about an almost ideal transformation of both his life and his writing.

Translated by Charles Rougle

I5 Conversation with Hubert Palm in Konstanz, June I989. Palm had been very impressed with "Intermedarius," and together with his mother had visited van der Meulen on several occasions in Monti. He and his mother received a modest inheritance from her. Van der Meulen had been buried at the S: te Orsola cemetery in Palermo.

I6 Conversations with Elisabeth Rezzonico-Valentin, November I99I, and with Lore Müller, July 2003 and July 2004. 


\section{Список литературы}

I Белый А. Начало века. Берлинская редакция (I923) / ред. А.В. Лавров. СПб.: Наука, 20I4. I064 с.

2 Белый А. Рудольф Штейнер и Гете в мировоззрении современности. Воспоминания о Штейнере / ред. И.Н. Лагутина, М.Л. Спивак. М.: Республика, 200о. 720 с.

3 Глуховская Е. Последний год «Мусагета»: Эллис между Э.К. Метнером и Белым // Арабески Андрея Белого / ред. К. Ичин, М.Л. Спивак. М.; Белград: Филологический факультет Белградского ун-та, 2016. С. 287-294.

4 Мальмстад Д. Белый и антропософия // Минувшее, г988. Т. 6. С. 337-450.

5 Эллис. Стихотворения. Томск: Водолей, І996. 288 с.

6 Юнггрен М. Русский Мефистофель: Жизнь и творчество Эмилия Метнера. СПб.: Академический проект, 200I. 288 с.

7 Юнггрен М. Эллис и доктор Кобилински - символист с двумя карьерами // Андрей Белый в изменяющемся мире. К І25-летию со дня рождения / ред. М.Л. Спивак, Е.В. Наседкина, И.Б. Делекторская. М.: Наука, 2008. С. 76-8о. Юнггрен М. Лев Кобылинский, Intermediarius и вице-бургомистр Винтер // На рубеже двух столетий. Сборник в честь 6о-летия А.В. Лаврова. М.: Новое Литературное Обозрение, 2009. С. 806-8I5.

9 Юнггрен M. Эмилий Метнер в жизни и сновидениях. Две заметки к теме // Russian Literature. 20I5. № LXXVII-IV. C. 409-4I8.

Io Boejtes I. Wer war Intermediarius? Leben und Werk einer ehemaligen Schülerin Rudolf Steiners (I) // Novalis. 200I. № I-2. P. 65-69.

Kobilinski-Ellis L. Christliche Weisheit. Sapientia divina. Cosmologia perennis nach der Lehre des Intermediarius. Basel: Buchdruckerei Frobenius A.-G., I929. I8I p. Ljunggren $M$. The Russian Mephisto. A Study of the Life and Work of Emilii Medtner. Stockholm: Almqvist \& Wiksell International, I994. 240 p. Pfleger K. Unionsgespräch mit einem “Römisch Orthodoxen” // Hochland. I934-I935. № 32. P. 363-370.

I4 Poljakov F. Literarische Profile von Lev Kobylinskij-Ėllis im Tessiner Exil. Forschungen-Texte-Kommentare. Cologne/Weimar/Vienna: Böhlau Verlag, 2000. 285 p. Rizzi D. Из архива H.А. Тургеневой: Письма Эллиса, А. Белого и А.А. Тургеневой // Europa Orientalis. I995. № I4/2. P. 30I-313.

I6 Vander Meulen J. О планетных сферах Дантова «Рая» в свете астрософии / пер. с гол. // Труды и дни. І9І6. № 8. С. 9-22.

I7 Willich H. Lev L. Kobylinskij-Ėllis. Von Symbolismus zur ars sacra. Eine Studie über Leben und Werk. Munich: Verlag Otto Sagner, I996. 299 p. 


\section{References}

I

Belyi A. Nachalo veka. Berlinskaia redaktsiia (1923) [The beginning of the century. Berlin edition], ed. A.V. Lavrov. St. Petersburg, Nauka Publ., 20I4. Io64 p. (In Russ.)

Belyi A. Rudol'f Shteiner $i$ Gete v mirovozzrenii sovremennosti. Vospominaniia o Shteinere [Rudol'f Steiner and Goethe in the religious worldview. Memoirs of Steiner], ed. I.N. Lagutina, M.L. Spivak. Moscow, Respublika Publ., 2000. 720 p. (In Russ.)

Glukhovskaia E. Poslednii god "Musageta”: Ellis mezhdu E.K. Metnerom i Belym [The last year of "Musaget": Ellis between E.K. Metner and Belyj]. Arabeski Andreia Belogo, [Andrey Belyj's arabesques], ed. K. Ichin, M.L. Spivak. Moscow, Belgrad, Philological Dept. Of Belgrad University Publ., 20I6, pp. 287-294. (In Russ.)

Mal'mstad D. Belyi i antroposofiia [Bely anthroposophy]. Minuvshee [The past], I988, vol. 6, pp. 337-450. (In Russ.)

Ellis. Stikhotvoreniia [Poems]. Tomsk, Vodolei Publ., I996. 288 p. (In Russ.)

Iunggren M. Russkii Mefistofel': Zhizn' i tvorchestvo Emiliia Metnera [Russian Mephistopheles: Life and work of Emilii Medtner]. St. Petersburg, Akademicheskii proekt Publ., 200I. 288 p. (In Russ.)

Iunggren M. Ellis i doktor Kobilinski - simvolist s dvumia kar'erami [Eliss and Dr. Kobilinski - a Symbolist with two careers]. Andrei Belyi v izmeniaiushchemsia mire. $K$ I25-letiiu so dnia rozhdeniia [Andrey Bely in the changing world: on his I25th anniversary], eds. M.L. Spivak, E.V. Nasedkina, I.B. Delektorskaia. Moscow, Nauka Publ., 2008, pp. 76-80. (In Russ.)

Iunggren M. Lev Kobylinskii, Intermediarius i vitse-burgomistr Winter [Lev Kobylinsky: Intermediarius and vice-mayor Vinter]. Na rubezhe dvukh stoletii. Sbornikv chest' 6o-letiia A.V. Lavrova [At the turn of two centuries: a collection in honor of A.V. Lavrov's 6oth anniversary]. Moscow, Novoe Literaturnoe Obozrenie, 2009, pp. 806-8I5. (In Russ.)

Iunggren M. Emilii Metner v zhizni i snovideniiakh. Dve zametki k teme [Emilii Metner in life and dreams. Two notes on the subject]. Russian Literature, 2015, no LXXVII-IV, pp. 409-4I8. (In Russ.)

Boejtes I. Wer war Intermediarius? Leben und Werk einer ehemaligen Schülerin Rudolf Steiners (I). Novalis, 200I, no I-2, pp. 65-69. (In German)

Kobilinski-Ellis L. Christliche Weisheit. Sapientia divina. Cosmologia perennis nach der Lehre des Intermediarius. Basel, Buchdruckerei Frobenius A.-G., I929. I8I p. (In German)

Ljunggren M. The Russian Mephisto. A Study of the Life and Work of Emilii Medtner. Stockholm, Almqvist \& Wiksell International, I994. 240 p. (In English)

Pfleger K. Unionsgespräch mit einem 'Römisch Orthodoxen'. Hochland, I934-I935, no 32, pp. 363-370. (In German)

Poljakov F. Literarische Profile von Lev Kobylinskij-Ëllis im Tessiner Exil. Forschungen-Texte-Kommentare. Cologne/Weimar/Vienna, Böhlau Verlag, 200o. 285 p. (In German)

5 Rizzi D. Iz arkhiva N.A. Turgenevoi: Pis'ma Ellisa, A. Belogo i A.A. Turgenevoi [From 
N.A, Turgeneva's archive: Letters by M.L. Ellis, A. Bely and A.A. Turgeneva]. Europa Orientalis, I995, no I4/2, pp. 30I-3I3. (In Russ.)

I6 Vander Meulen J. O planetnykh sferakh Dantova "Raia” v svete astrosofii [About planetary spheres of Dante's "Paradiso" in the light of astrosophy], Trans. from Dutch. Trudy $i$ dni, I916, no 8, pp. 9-22. (In Russ.)

I7 Willich H. Lev L. Kobylinskij-Ellis. Von Symbolismus zur ars sacra. Eine Studie über Leben und Werk. Munich, Verlag Otto Sagner, I996. 299 p. (In German) 